\title{
PENGARUH REINFORCEMENT GURU TERHADAP KOMPETENSI AFEKTIF SISWA SMA JAKARTA TIMUR DALAM MEMINIMALISIR BERITA HOAX
}

\author{
Agus Abdillah, Hendro Prasetyono \\ Dosen Program Studi Pendidikan Ekonomi Universitas Indraprasta PGRI \\ Email : gusti_cokrodiningrat@yahoo.co.id, hendro_prasetyono@unindra.ac.id
}

\begin{abstract}
Abstrak
Penelitian ini bertujuan untuk mengetahui dan menganalisis pengaruh reinforcement guru terhadap kompetensi afektif siswa SMA Jakarta Timur dalam meminimalisir berita hoax di media sosial online. Jenis penelitian ini adalah deskriptif asosiatif. Populasi penelitian ini adalah seluruh siswa kelas X SMA di Jakarta Timur tahun ajaran 2017/2018 yang sebelumnya dipilih secara kluster berjumlah 1.793 siswa. Selanjutnya pengambilan sampel dengan proportional random sampling diperoleh sampel sebanyak 95 siswa. Teknik analisis data adalah analisis deskriptif dan analisis regresi. Hasil penelitian menunjukan bahwa terdapat pengaruh yang positif dan signifikan reinforcement guru terhadap kompetensi afektif siswa SMA Jakarta Timur dalam meminimalisir berita hoax di media sosial online. Koefisien determinan $\left(\mathrm{R}^{2}\right)$ yang diperoleh $(0,333)^{2}$ sebesar 0,111 . Hal ini menunjukkan bahwa reinforcement guru memberikan kontribusi terhadap kompetensi afektif siswa sebesar 11,1\%, sedangkan sisanya sebesar 88,9\% disumbangkan oleh faktor lain yang tidak diteliti dalam penelitian ini.
\end{abstract}

Kata kunci: Kompetensi Afektif Siswa, Reinforcement Guru, SMA di Jakarta Timur

\section{PENDAHULUAN}

Istilah berita hoax sebenarnya sudah lama beredar seiring dengan perkembangan teknologi dan informasi. Media sosial berbasis smart phone seperti Facebook, Line, BBM, WhatsApp, GoogleApp, dan sederet aplikasi media sosial online lainnya dewasa ini seolah-olah menjadi kebutuhan pokok masyarakat, tidak ketinggalan pula pada kalangan remaja atau siswa. Harga smart phone yang relatif terjangkau, membuat siswa mudah memilikinya.

Fenomena saat ini, media sosial online bagi siswa merupakan ajang untuk mempererat persahabatan, mendapatkan teman baru, berbagi atau sharing/curhat, aktualisasi diri, dan sering dijadikan ajang untuk mempromosikan barang dan jasa. Dengan kata lain belajar menjadi pebisnis kecil-kecilan berbasis online/ecommerce. Hal itu tidak menjadi masalah sepanjang dalam koridor etika yang benar. Artinya kehadiran media sosial online memiliki peran positif bagi siswa. Kenyataan yang terjadi sekarang ini, beberapa komunitas yang berstatus siswa sering berkata atau menulis pesan yang kurang layak, tidak santun, tidak jujur, kurang toleransi, tidak bertanggungjawab, illegitimate, dan lain sebagainya yang justru menimbulkan masalah atau konfliks. Masalah tersebut tentu 
mengindikasikan kompetensi afektif siswa yang relatif masih kurang. Hal ini karena tidak sesuai dengan dimensi kompetensi afektif antara lain; respons dan kompetensi membangun relasi dengan diri sendiri, respons dan kompetensi membina relasi dengan orang lain, respons dan kompotensi membangun relasi dengan lingkungan yang selalu berubah, dan respons dan kompetensi membangun relasi dengan Tuhan sebagai Sang Pencipta dan tujuan perjalanan kehidupan.

Keberadaan UU yang komprehensif mengatur perilaku di dunia maya sangat mendesak, mengingat saat ini negara dinilai tak berdaya mengatasi maraknya hoax. KUHP dan UU ITE belum mampu menyasar produsen sekaligus penyebar berita palsu. Oleh karena itu, penulis ingin memberikan sumbangsih, mencoba untuk mencari salah satu problem solving yaitu dari aspek pendidikan. Sebab dimulai dari pendidikan dan pembelajaran, bangsa ini menjadi beradab. Pendidikan mampu mengatasi dekadensi moral. Pendidikan mampu meningkatkan harkat dan martabat suatu bangsa.

Berdasarkan hasil pengamatan sementara yang telah penulis lakukan secara prasurvei di beberapa SMA di Kecamatan Pasar Rebo, Jakarta Timur menunjukkan bahwa masih ada siswa yang kompetensinya belum optimal, secara rata-rata hanya $78,67 \%$ siswa kompeten dalam sikap, sisanya adalah $21,33 \%$ siswa perlu perhatian khusus. Siswa yang perlu perhatian khusus mengindikasikan bahwa siswa belum menunjukkan sikap yang baik, belum menunjukkan sikap jujur, masih terdapat siswa yang sering melontarkan kata-kata kasar, kurangnya sikap toleransi antar siswa, acuh tak acuh dan sebagainya. Jika hal ini belum ada tindak lanjut yang berarti, maka implikasinya adalah akan semakin menurunnya kompetensi afektif pada diri siswa.

Setiap muncul permasalahan kompetensi afektif siswa, faktor penting yang memberikan kontribusi adalah input dan proses pembelajaran. Pada kesempatan ini yang akan dikaji adalah dari faktor proses pembelajaran yaitu pemberian penguatan (reinforcement) guru kepada peserta didik. Studi pendahuluan yang dilakukan di beberapa sekolah menunjukan masih belum intenif reinforcement guru. Belum intensifnya reinforcement guru di beberapa sekolah tersebut, penulis mengasumsikan bahwa hal ini bisa terjadi juga di SMA-SMA lain di Jakarta Timur. Selanjutnya berdasarkan opini siswa yang penulis himpun, kecenderungan 
guru masih mengajar berdasarkan tugas pokok. Guru belum optimal dalam memberikan penguatan (reinforcement) kepada siswa

Tujuan penelitian ini adalah untuk mengetahui dan menganalisis pengaruh reinforcement guru terhadap kompetensi afektif siswa SMA Jakarta Timur dalam meminimalisir berita hoax di media sosial online. Manfaat yang diharapkan dari penelitian ini yaitu, memberikan pengaruh yang berdaya guna secara teoritis, metodologis dan empiris bagi kepentingan akademis dalam bidang pendidikan, dapat dijadikan suatu pola dan strategi dalam meningkatkan hasil belajar pada ranah afektif. Bagi pengembangan ilmu pengetahuan, sebagai sarana pengembangan ilmu pengetahuan evaluasi pembelajaran khususnya tentang pentingnya peran guru dalam meningkatkan kompetensi afektif siswa. Bagi Stakeholder, sebagai masukan kepada Dinas Pendidikan dan Sekolah dalam mengambil kebijakan terutama mengenai permasalah ini. Tulisan ini dijadikan salah satu sumber bacaan yang dapat dipertimbangkan dalam pemecahan masalah yang relevan.

Selanjutnya bagi peneliti lebih lanjut, sebagai tambahan referensi bagi masyarakat ilmiah yang berminat melakukan penelitian pada bidang yang sama khususnya mengenai masalah pendidikan.

\section{TINJAUAN PUSTAKA}

\section{Kompetensi Afektif Siswa}

Kompetensi afektif merupakan kemampuan yang berkaitan dengan perilaku dan sikap seseorang. Afektif meliputi sikap, nilai-nilai, interest, apresiasi dan penyesuaian perasaan sosial (Uno, 2010:70). Sedangkan menurut Arifin (2009:22) afektif yaitu internalisasi sikap yang menunjukan pertumbuhan batiniah seseorang sehingga sadar akan nilai-nilai yang diterima dan ditunjukkan dengan perilaku yang lebih baik.

Selanjutnya Chatib (2009:99) mengatakan bahwa kompetensi ranah afektif meliputi peningkatan pemberian respons, sikap, apresiasi, penilaian, minat, dan internalisasi. Penilaian afektif terutama bertujuan untuk mengetahui karakter siswa dalam proses pembelajaran dan hasil dari pembelajaran dapat dibagi menjadi; penilaian afektif pada saat proses belajar berlangsung, penilaian afektif di luar proses belajar di dalam sekolah, penilaian afektif di luar sekolah atau di rumah. 
Secara sederhana, kompetensi afektif mempunyai empat dimensi utama, yaitu berupa respons dan kompetensi membangun relasi dengan diri sendiri, repons dan kompetensi membina relasi dengan orang lain, respons dan kompotensi membangun relasi dengan lingkungan yang selalu berubah, dan respons dan kompetensi membangun relasi dengan Tuhan sebagai Sang Pencipta dan tujuan perjalanan kehidupan (Chatib, 2012:83).

\section{Reinforcement Guru}

Menurut Wibowo (2015:17) reinforcement atau penguatan merupakan salah satu teori motivasi yang bertujuan agar terjadinya pengulangan terhadap tingkah laku yang diberi penguatan. Bentuk penguatan yang diberikan oleh guru terhadap tingkah laku positif yang ditunjukkan oleh siswa dapat berupa pemberian reward dalam bentuk benda (hadiah), verbal (seperti pujian), dan juga dalam bentuk tingkah laku yang hangat, permisif, dan penuh penerimaan. Sedangkan penguatan negative (punishment) adalah sesuatu yang apabila ditiadakan akan meningkatkan respon.

\section{METODE}

Berdasarkan kepada permasalahan yang akan diteliti, maka penelitian ini tergolong pada jenis penelitian deskriptif dan asosiatif. Populasi penelitian ini adalah seluruh siswa kelas X Ilmu Sosial SMA Negeri dan Swasta di Jakarta Timur. Jumlah populasi dalam penelitian ini sebanyak 1.793 siswa. Melihat jumlah populasi yang cukup besar, maka pengambilan sampel dilakukan dengan teknik proporsional random sampling, dimana sampel diambil secara acak, dan secara proporsional berdasarkan jumlah siswa dari masing-masing sekolah yang diteliti (Sugiyono, 2008:115). Adapun jumlah sampel yang telah dihitung dengan rumus Slovin, diperoleh sampel sebanyak 95 siswa. Untuk teknik pengumpulan data penelitian ini digunakan dengan metode angket dan dokumentasi. Teknik analisis data dalam penelitian ini yaitu analisis deskriptif dan analisis regresi.

\section{HASIL DAN PEMBAHASAN}

Analisis Deskriptif

Distribusi frekuensi Kompetensi Afektif dengan indikator Respons dan kompetensi membangun relasi dengan diri sendiri dapat diketahui rerata skor 3,76 dengan tingkat ketercapaian responden yaitu 75,16. Angka ini berada pada rentang $71 \%$ - $85 \%$ dapat dikatakan kompetensi afektif siswa pada indikator 
Research and Development Journal Of Education

Vol. 5 No. 1 Oktober 2018

ISSN 2406-9744

respons dan kompetensi membangun relasi dengan diri sendiri berkategori baik. Artinya bahwa siswa SMA di Jakarta Timur memiliki memiliki rasa percaya diri, tanggungjawab, kejujuran yang bagus.

Kemudian pada indikator repons dan kompetensi membina relasi dengan orang lain skor rata-rata 3,99 dengan tingkat ketercapaian responden sebesar $79,79 \%$. Angka ini berada pada rentang 71\% - 85\%. Artinya siswa memiliki repons dan kompetensi membina relasi dengan orang lain yaitu rasa peduli, menghargai orang lain dikatakan baik. Sedangkan pada indikator respons dan kompetensi membangun relasi dengan lingkungan, tingkat ketercapaian responden sebesar 79,16\%. Angka ini berada pada rentang 71\% - 85\%. Artinya respons dan kompetensi membangun relasi dengan lingkungan yang dimiliki oleh siswa dalam hal ini siswa dalam beradaptasi dengan lingkungan, mematuhi aturan/norma dapat dikatakan baik. Selanjutnya pada indikator Respons dan kompetensi membangun relasi dengan Tuhan, tingkat ketercapaian responden sebesar 84,63\%. Angka ini berada pada rentang $71 \%-85 \%$. Artinya rata-rata siswa memiliki keimanan dan ketaqwaan kepada Tuhan Yang Maha Esa dalam kategori baik. Tingkat ketercapaian responden untuk variabel kompetensi afektif siswa adalah 80,00\%, Hal ini bermakna bahwa secara rata-rata kompetensi afektif siswa SMA di Kota Jakarta Timur berkategori baik.

Tabel 1. Distribusi Frekuensi Kompetensi Afektif Siswa

\begin{tabular}{|c|c|c|c|c|c|c|c|c|c|c|c|c|c|c|}
\hline \multirow{2}{*}{ No. } & \multirow{2}{*}{ Indikator } & \multicolumn{2}{|c|}{$\begin{array}{l}\text { Sangat } \\
\text { Setuju }\end{array}$} & \multicolumn{2}{|c|}{ Setuju } & \multicolumn{2}{|c|}{$\begin{array}{c}\text { Biasa- } \\
\text { biasa Saja }\end{array}$} & \multicolumn{2}{|c|}{ Kurang Setuju } & \multicolumn{2}{|c|}{$\begin{array}{l}\text { Tidak } \\
\text { Setuju } \\
\end{array}$} & \multirow{2}{*}{$\frac{\text { Rerata }}{\text { (mean) }}$} & \multirow{2}{*}{$\frac{\mathrm{TCR}}{(\%)}$} & \multirow[t]{2}{*}{ Ket. } \\
\hline & & $F i$ & $\%$ & $F i$ & $\%$ & $F i$ & $\%$ & $F i$ & $\%$ & $F i$ & $\%$ & & & \\
\hline 1 & $\begin{array}{l}\text { Respons dan } \\
\text { kompetensi } \\
\text { membangun relasi } \\
\text { dengan diri sendiri }\end{array}$ & 19 & 20.00 & 38 & 40.00 & 34 & 35.79 & 4 & 4.21 & 0 & 0.00 & 3.76 & 75.16 & Baik \\
\hline 2 & $\begin{array}{l}\text { Repons dan } \\
\text { kompetensi membina } \\
\text { relasi dengan orang } \\
\text { lain }\end{array}$ & 29 & 30.53 & 48 & 50.53 & 16 & 16.84 & 2 & 2.11 & 0 & 0.00 & 3.99 & 79.79 & Baik \\
\hline 3 & $\begin{array}{l}\text { Respons dan } \\
\text { kompotensi } \\
\text { membangun relasi } \\
\text { dengan lingkungan }\end{array}$ & 33 & 34.74 & 31 & 32.63 & 26 & 27.37 & 4 & 4.21 & 1 & 1.05 & 3.96 & 79.16 & Baik \\
\hline 4 & $\begin{array}{l}\text { Respons dan } \\
\text { kompetensi } \\
\text { membangun relasi } \\
\text { dengan Tuhan } \\
\end{array}$ & 38 & 40.00 & 42 & 44.21 & 14 & 14.74 & 1 & 1.05 & 0 & 0.00 & 4.23 & 84.63 & Baik \\
\hline & Rerata Variabel & 29 & 30.53 & 40 & 42.11 & 23 & 24.21 & 3 & 3.16 & 0 & 0.00 & 4.00 & 80.00 & Baik \\
\hline
\end{tabular}


Research and Development Journal Of Education

Vol. 5 No. 1 Oktober 2018

ISSN 2406-9744

Pada tabel 2, yaitu ringkasan tabel distribusi frekuensi reinforcement guru dengan indikator reinforcement positif dapat diketahui skor rata-rata 3,33 dengan tingkat ketercapaian responden untuk indikator tersebut yaitu 66,53\%. Angka ini berada pada rentang $56 \%$ - 70\%, Artinya reinforcement guru pada indikator tersebut dikategorikan masih biasa-biasa saja atau dapat dikatakan guru masih belum cukup memberikan penguatan positif seperti memberikan hadiah, pujian apresiasi kepada siswa.

Sedangkan reinforcement guru pada indikator reinforcement negatif dapat diketahui skor rerata sebesar 3,04 dengan tingkat ketercapaian responden sebesar $60,82 \%$. Angka ini berada pada rentang 56\% - 70\% yang berarti bahwa guru masih belum memberikan penguatan negative seperti memberi punishment atau hukuman atau sanksi kepada siswa yang membuat masalah dalam kegiatan belajar mengajar. Masih sedang-sedang saja. Seharusnya ditingkatkan. Tingkat capaian responden dari masing-masing indikator untuk variabel reinforcement guru, dapat diketahui rerata variabelnya yaitu sebesar $61,68 \%$. Angka ini berada pada rentang $56 \%$ - 70\% yang berarti reinforcement guru SMA di kota Jakarta Timur pada kategori Sedang-sedang saja.

Tabel 2. Distribusi Frekuensi Reinforcement Guru

\begin{tabular}{|c|c|c|c|c|c|c|c|c|c|c|c|c|c|c|}
\hline \multirow[t]{2}{*}{ No. } & \multirow{2}{*}{ Indikator } & \multicolumn{2}{|c|}{ Selalu } & \multicolumn{2}{|c|}{ Sering } & \multicolumn{2}{|c|}{$\begin{array}{c}\text { Kadang- } \\
\text { kadang }\end{array}$} & \multicolumn{2}{|c|}{ Jarang } & \multicolumn{2}{|c|}{$\begin{array}{l}\text { Tidak } \\
\text { pernah } \\
\end{array}$} & \multirow{2}{*}{$\frac{\text { Rerata }}{(\text { mean })}$} & \multirow{2}{*}{$\frac{\mathrm{TCR}}{(\%)}$} & \multirow[t]{2}{*}{ Ket. } \\
\hline & & $F i$ & $\%$ & $F i$ & $\%$ & $F i$ & $\%$ & $F i$ & $\%$ & $F i$ & $\%$ & & & \\
\hline 1 & $\begin{array}{l}\text { Pemberian } \\
\text { penguatan positif }\end{array}$ & 18 & 18.95 & 27 & 28.42 & 27 & 28.42 & 14 & 14.74 & 9 & 9.47 & 3.33 & 66.53 & Sedang \\
\hline 2 & $\begin{array}{l}\text { Pemberian } \\
\text { penguatan negatif }\end{array}$ & 10 & 10.53 & 24 & 25.26 & 21 & 22.11 & 19 & 20.00 & 21 & 22.11 & 3.04 & 60.82 & Sedang \\
\hline & Rerata Variabel & 14 & 14.74 & 26 & 27.37 & 24 & 25.26 & 16 & 16.84 & 15 & 15.79 & 2.93 & 61.68 & Sedang \\
\hline
\end{tabular}

Sumber : Pengolahan Data Primer Tahun 2018

\section{Analisis Regresi}

Berdasarkan uji statistikdapat diketahui nilai konstanta $=22.061$, sedangkan koefisien regresi linear $b=X(0.333)$. Dengan demikian diperoleh persamaan regresi linear sebagai berikut::

$$
\begin{aligned}
Y_{i} & =a+b X+e \\
\hat{Y}_{i} & =40.274+0.226 X
\end{aligned}
$$

Reinforcement guru nilai estimasi regresi adalah 0,226. Dapat diartikan apabila reinforcement guru ditingkatkan sebesar 1 satuan, maka kompetensi afektif siswa akan meningkat sebesar 0,226 satuan. Sumbangan reinforcement 
guru terhadap kompetensi afektif siswa sebesar 0,333 dengan asumsi variabel lain tetap. Sementara koefisien determinan $\left(\mathrm{R}^{2}\right)$ yang diperoleh $(0,333)^{2}$ sebesar 0,111 . Hal ini menunjukkan bahwa reinforcement guru memberikan kontribusi terhadap kompetensi afektif siswa sebesar 11,1\%, sedangkan sisanya sebesar 88,9\% disumbangkan oleh faktor lain yang tidak terindentifikasi dalam penelitian ini. Selain itu, tingkat pengaruh faktor reinforcement guru terhadap kompetensi afektif siswa adalah sebesar 33,3\%.

Tabel 3. Regresi Linear Sederhana

\begin{tabular}{|c|c|c|c|c|c|c|c|}
\hline \multirow{2}{*}{\multicolumn{2}{|c|}{ Model }} & \multicolumn{2}{|c|}{ Unstandardized Coefficients } & \multirow{2}{*}{$\begin{array}{c}\text { Standardized } \\
\text { Coefficients } \\
\text { Beta }\end{array}$} & \multirow[t]{2}{*}{$\mathrm{t}$} & \multirow{2}{*}{ Sig. } & \multirow{2}{*}{ Information } \\
\hline & & $\mathrm{B}$ & Std.Error & & & & \\
\hline 1 & (Constant) & 40.274 & 2.285 & & 17.622 & 0.000 & \multirow[b]{2}{*}{$\mathrm{H}_{0}$ rejected } \\
\hline & Reinforcement & 0.226 & 0.066 & 0.333 & 3.406 & 0.001 & \\
\hline
\end{tabular}

Hasil pengujian hipotesis diperoleh thitung sebesar 3,406 sedangkan $t$ tabel 1,986. Hal ini menunjukkan bahwa $t_{h i t}>t_{t a b}(3,406>1,986)$, dapat dikatakan bahwa hipotesis nol $\left(\mathrm{H}_{0}\right)$ ditolak. Artinya terdapat pengaruh positif dan signifikan reinforcement guru terhadap kompetensi afektif siswa.

Berdasarkan hasil pengujian hipotesis dapat diketahui bahwa reinforcement guru memiliki pengaruh yang positif dan signifikan terhadap kompetensi afektif siswa kelas X Ilmu Sosial SMA di Jakarta Timur. Hal ini dapat diartikan bahwa apabila reinforcement guru meningkat, dalam hal ini dilaksanakan secara intensif dan berkelanjutan, maka kompetensi afektif siswa dalam meminimalisir berita hoax akan meningkat. Sebaliknya, apabila reinforcement guru menurun, dalam hal ini jarang atau bahkan tidak dilaksanakan, maka kompetensi afektif siswa dalam meminimalisir berita hoax akan mengalami penurunan. Berdasarkan hasil analisis deskriptif, tingkat capaian responden untuk variabel reinforcement guru hanya sebesar $61,68 \%$. Sementara tingkat capaian responden untuk variabel kompetensi afektif siswa sebesar $80,00 \%$. Oleh karena itu, kontribusi reinforcement guru terhadap kompetensi afektif siswa hanya sebesar $11,1 \%$.

Hasil penelitian ini diperkuat oleh beberapa penelitian sebelumnya antara lain; Andi Makkawari Latif, Muchlisah, dan Eka Damayanti (2017).

\section{SIMPULAN}

Berdasarkan hasil dan pembahasan penelitian tentang pengaruh reinforcement guru terhadap kompetensi afektif siswa SMA di Jakarta Timur 
dalam meminimalisir hoax, penulis menyimpulkan bahwa reinforcement guru berpengaruh positif dan signifikan terhadap kompetensi afektif siswa kelas $\mathrm{X}$ SMA di Jakarta Timur. Hal ini berarti tinggi rendahnya reinforcement guru tidak begitu mempengaruhi peningkatan kompetensi afektif siswa.

\section{UCAPAN TERIMA KASIH}

Penelitian dan penulisan artikel ini didanai oleh Kemristek Dikti DIPA: Direktorat Penelitian dan Pengabdian Kepada Masyarakat No. Kontrak: 032/PNT/2018, tanggal 06 Maret 2018 dengan skema "PDP". Oleh karena itu, penulis mengucapkan terima kasih yang tak terhingga. Ini merupakan suatu kebanggan bagi penulis untuk meningkatkan kapasitas. Penulis juga memberikan apresiasi yang tulus kepada seluruh kepala sekolah, guru, staf, dan seluruh siswa SMA di Jakarta Timur yang telah perpartisipasi sehingga penelitian ini terselesaikan dengan baik dan tepat waktu.

\section{DAFTAR PUSTAKA}

A.M. Latif, Muchlisah, dan E. Damayanti. 2010. Pengaruh Teknik Reinforcement Terhadap Hasil Belajar Biologi Pokok Bahasan Sistem Peredaran Darah Manusia.Jurnal Biotek Vol. 5 (1).

Arifin, Zaenal. 2009. Evaluasi Pembelajaran: Prinsip, Teknik, dan Prosedur. Bandung: Remaja Rosda Karya.

Chatib, Munif. 2009. Sekolahnya Manusia: Sekolah Berbasis Multiple Intelligences Di Indonesia. Bandung: Kaifa.

. 2012. Orang Tuanya Manusia: Melejitkan Potensi dan Kecerdasan Dengan Menghargai Fitrah Setiap Anak. Bandung: Kaifa.

Sugiyono. 2003. Metode Penelitian Bisnis. Bandung. Pusat Bahasa Depdiknas.

Uno, Hamzah B. 2010. Perencanaan Pembelajaran. Jakarta: Bumi Aksara.

Wibowo, Agus. 2015. Aplikasi Reinforcement oleh Guru Mata Pelajaran dan Implikasinya Terhadap Bimbingan dan Konseling. Guidena, Jurnal Ilmu Pendidikan, Psikologi, Bimbingan dan Konseling, Vol. 5 No. 2. ISSN 2088-9623. 